Chirurgia (2019) 114: 461-466

No. 4, July - August

Copyright $\odot$ Celsius

http://dx.doi.org/10.21614/chirurgia.114.4.461

\title{
Appendicular Neuroendocrine Neoplasm is Associated with Acute Appendicitis - Don't Miss the Boat
}

\author{
Khalid Khan, Sangram Patil, Shahid Roomi, Muhammad Hanif Shiwani \\ Department of Surgery, Barnsley District General Hospital, South Yorkshire, United Kingdom of Great Britain \& Northern Ireland
}

Corresponding author:

Khalid Khan, FCPS FRCS

Department of surgery, Gawber road

Barnsley, South Yorkshire S752EP

United Kingdom of Great Britain \&

Northern Ireland

E-mail: khalidoonkhan@hotmail.com

\section{Rezumat}

Neoplazia neuroendocrină a apendicelui este asociată cu apendicita acută - Nu ratați trenul!

Context: Neoplaziile neuroendocrine ale apendicelui (ANEN) sunt tumori rare diagnosticate incidental în timpul histopatologiei efectuată după apendicectomie, realizată pentru a trata o apendicită acută. Rata de supraviețuire la cinci ani după ANEN diagnosticată timpuriu, cu ganglioni limfatici negativi este de 90\%. Totuşi, tendința în creştere de a trata apendicita folosind doar antibiotic poate duce la ignorarea acestori tumori fără simptome. Studiul de față are ca scop evaluarea incidenței şi a managementului ANEN descoperită în piesele operatorii rezultate în urma apendicectomiei, realizată pentru apendicită acută.

Metode: A fost efectuat un studiu retrospectiv, care a inclus toți pacienții supuşi apendicectomiei la spitalul Barnsley în perioada 2009 - 2015, fiind suspecți de apendicită acută, cu atenție deosebită la incidență, investigații şi rezultatul ANEN.

Rezultate: În perioada 2009 - 2015, 1562 de apendicectomii au fost efectuate pentru apendicită acută, 11 piese operatorii relevând tumori neuroendocrine $(0.70 \%)$. Vârsta medie a pacienților a fost de 31,73 ani, 81,8\% fiind femei. Opt pacienți au fost supuşi apendicectomiei laparoscopice (72.7\%), doi pacienți apendicectomiei deschise $(18.2 \%)$, iar în cazul unui pacient apendicectomia laparoscopică s-a transformat în intervenție deschisă. Dimensiunea tumorii a fost $<10 \mathrm{~mm}$ la şase pacienți (54.5\%) şi între $10-20 \mathrm{~mm}$ la patru pacienți (36.4\%). Majoritatea tumorilor au fost localizate la baza / în corpul apendicelui (54.5\%). Toate tumorile au fost bine diferențiate, stadiul 1. În nouă cazuri marginile de rezecție au fost clare; doi pacienți au avut nevoie de hemicolectomie dreaptă deschisă. Din grupul nostru de pacienți, 
trei (27.27\%) au fost urmăriți prin efectuarea unui CT la doi ani de la intervenție, neexistând nici o recidivă.

Concluzii: Apendicectomia este procedura de elecție pentru majoritatea ANEN. După cum arată studiul nostru, în cazul în care apendicita acută este tratată folosind doar tratament conservator, există un risc mai scăzut de $1 \%$ de a rata diagnosticarea ANEN. De asemenea, doi dintre pacienți sufereau de afecțiuni locale avansate. Acestea ar fi putut avea cu siguranță un prognostic rezervat în lipsa apendicectomiei.

Cuvinte cheie: apendicită, tumoră neuroendocrină, apendice, neoplazii ale apendicelui

\section{Abstract}

Background: Appendicular neuroendocrine neoplasms (ANEN) are rare tumours diagnosed incidentally on histology after an appendicectomy carried out for acute appendicitis. Five years survival rate of node-negative an early ANEN is over 90\%. However, the growing interest, among clinicians, to treat appendicitis by antibiotics only, could potentially miss these indolent tumours. The aim of our study was to look at the incidence and management of ANEN discovered in appendicectomy specimens carried out for acute appendicitis.

Methods: A retrospective review was performed for all patients undergone appendicectomy, at Barnsley hospital from 2009 to 2015, as suspected acute appendicitis, with particular focus on incidence, investigations and outcome of ANEN.

Results: During 2009-2015, 1562 appendicectomies were carried out for acute appendicitis, with 11 specimens showed neuroendocrine tumours $(0.70 \%)$. Mean age of patients was 31.73 years, with $81.8 \%$ female. 8 patients had laparoscopic appendicectomy (72.7\%), 2 had open appendicectomy $(18.2 \%)$, while one had laparoscopic converted to open appendicectomy. Tumour size was less $10 \mathrm{~mm}$ in 6 patients $(54.5 \%)$, between $10-20 \mathrm{~mm}$ in $4(36.4 \%)$. Majority were located at the body/base of appendix (54.5\%). All tumours were grade 1 well differentiated tumours. 9 patients had clear resection margins, while two patients needed further surgery as an open right hemicolectomy as a curative procedure. In our series, 3 patients $(27.27 \%)$ had follow up scans 2 years after surgery and showed no tumour recurrence.

Conclusion: Appendicectomy is the curative procedure for the majority of ANEN. As shown in our study, if acute appendicitis is managed with conservative treatment only, there is less than $1 \%$ risk of missing the diagnosis of ANEN. Also, two of our patients had locally advanced diseases. These could definitely have a poor prognosis without ap-pendectomy.

Key words: appendicitis, neuroendocrine tumor, appendix, appendiceal neoplasms

\section{Introduction}

Acute appendicitis is a common surgical condition with the life time risk of $6.7-8.6 \%$ (1). Over recent years, there have been growing interests in treating uncompli-cated acute appendicitis with antibiotics only. Various randomised controlled trials have demonstrated fewer complications with conservative approach $(2-5)$. However, treating acute appendicitis with antibiotic only approach would be missing appendiceal tumours, found incidentally in appendicectomy specimens, which are predominantly appendiceal neuroendocrine neoplasms (ANEN). These are rare, slow growing, usually asymptomatic tumours, discovered incidentally in an appendicectomy specimens, carried out both as an emergency procedure, and in an electively performed interval appendicectomy specimens too (6-8). If treated early, 
an index appendicectomy is the curative treatment for the majority of incidental ANEN (7). A node negative and well differentiated early ANEN has 5 years survival of over 90\% (9). On other hand, an advanced metastatic disease has a poor prognosis with 5 years survival as $12-18 \%(7)$.

A retrospective review was performed for all patients undergone appendicectomy as suspected acute appendicitis, with particular focus on the incidence of ANEN and their investigations. We also review the outcome of these patients, who we found to have ANEN in the specimen resected.

\section{Methods}

A retrospective review of patients, who underwent emergency appendicectomy for suspected acute appendicitis at Barnsley hospital from 2009 to 2015. Data were collected from hospital electronic database (ORMIS, Bluesper and ICE). Patients, with histological confirmation of neuroendocrine tumours, were included in the study. Demographic details, clinical presentation, inflammatory markers, operative findings and post operative follow up information were collected. Information regarding histological details were recorded. This included site, size, grade \& degree of differentiation of tumour, histological staging and resections margins.

Statistical analysis was performed using SPSS version 20.0 R (IBM corporation, Armonk, USA). Categorical variables were presented as actual numbers and percentages (\%). Continuous variables were represented as mean.

\section{Results}

A total of 1562 appendicectomies were carried out at our institution between 2009 and 2015 for acute appendicitis. 11 specimens showed neuroendocrine tumours (0.70\%). Mean age of patients was 31.73 years (range $13-49$ years). With female preponderance (81.8\%). All patients had clinical features, supported by raised inflammatory markers, suggestive of

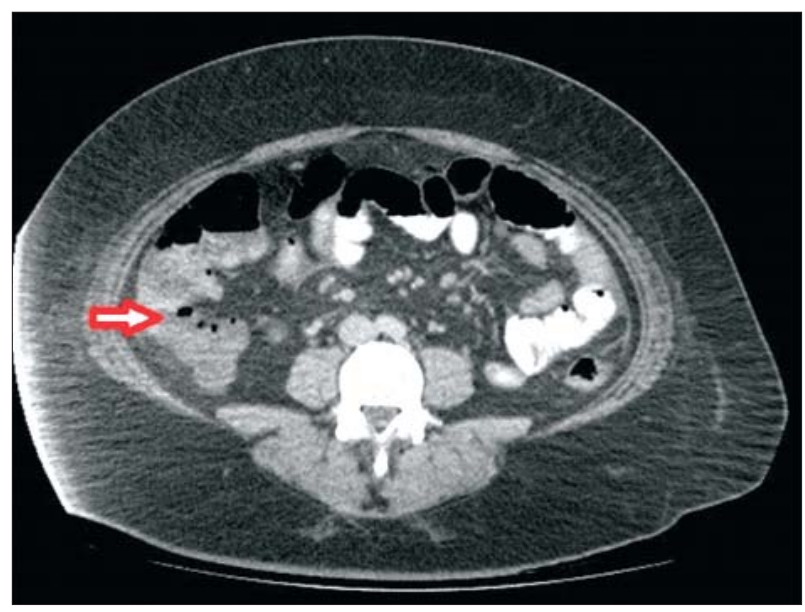

Figure 1. CT scan showing acute appendicitis (arrow)

acute appendicitis. Preoperatively, in a case, where there was diagnostic uncertainty, one patient had preoperative CT scan. This showed acute appendicitis. It didn't raised any suspicion of neoplasia (Fig. 1). In our institution, it has been the standard practice to treat acute appendicitis by appendicectomy. 8 patients had laparoscopic appendicectomy (72.7\%), 2 had open appendicectomy (18.2\%), while one had laparoscopic converted to open appendicectomy (Table 1). Intra operatively, none of patients had any suspicion of neoplastic lesion.

Histology confirmed background inflammation in 9 cases but 2 were normal appendix

Table 1. Demographic, Presentation \& Operative Findings (Total Number 11)

\begin{tabular}{|c|c|c|}
\hline \multirow[t]{2}{*}{ Gender } & Male & $2(18.2 \%)$ \\
\hline & Female & $9(81.8 \%)$ \\
\hline \multirow[t]{3}{*}{ Age (in years) } & Min & 13 \\
\hline & Max & 49 \\
\hline & Mean & 31.72 \\
\hline \multirow{3}{*}{$\begin{array}{l}\text { Raised Inflammatory } \\
\text { markers }\end{array}$} & Raised WCC* & $4(36.4 \%)$ \\
\hline & Raised CRP** & $2(18.2 \%)$ \\
\hline & Raised WCC*\& CRP** & $5(45.5 \%)$ \\
\hline \multirow[t]{3}{*}{ Operation } & Open appendicectomy & $2(18.2 \%)$ \\
\hline & Laparoscopic & $8(72.7 \%)$ \\
\hline & Lap converted to open & $1(9.1 \%)$ \\
\hline \multirow[t]{5}{*}{ Findings } & Acutely inflamed appendix & $7(63.6 \%)$ \\
\hline & Perforated appendix & $1(9.1 \%)$ \\
\hline & Possibly inflamed & $1(9.1 \%)$ \\
\hline & Gangrenous \& perforated appendix & $1(9.1 \%)$ \\
\hline & Normal looking appendix & $1(9.1 \%)$ \\
\hline
\end{tabular}

*White Cell Count; ${ }^{*}$ C-Reactive Protein 
along with ANEN. On histological assessment, tumour size was less $10 \mathrm{~mm}$ in 6 patients (54.5\%), between $10-20 \mathrm{~mm}$ in $4(36.4 \%)$, while one had tumour size of more than $2 \mathrm{~cm}$. Majority were located at the tip of appendix $(45.5 \%)$. Pathological staging in six patients was pT1, while three patients had pathological stage pT2, pT3 and pT4 for one patient each. All tumours were well differentiated, with no lymphovascular invasion, grade 1 tumours with 2 mitosis and less than 2\% Ki67 index (Figs. 2 - 4). 9 patients had clear resection margin. One patient had involved margin and other had extension into mesoappendix on histology (Table 2). Where patient has positive margin showed features of $\mathrm{pT} 3 \mathrm{Nx}$ and the other patient where the original specimen showed involvement of mesoappendix had features of $\mathrm{pT} 1 \mathrm{Nx}$. Both these patients underwent further surgery, open right hemicolectomy as a curative procedure. Histology of right hemicolectomy specimen showed no residual tumour.

Table 2. Histology \& Further Treatment (Total Number 11)

\begin{tabular}{|c|c|c|}
\hline $\begin{array}{l}\text { Histological } \\
\text { details }\end{array}$ & $\begin{array}{l}\text { Size of tumor } \\
-<10 \mathrm{~mm} \\
-10-20 \mathrm{~mm} \\
->20 \mathrm{~mm}\end{array}$ & $\begin{array}{c}6(54.5 \%) \\
4(36.4 \%) \\
1(9.1 \%)\end{array}$ \\
\hline & $\begin{array}{l}\text { Differentiation \& Grade of tumour } \\
\text { - Grade } 1 \text { \& Well differentiated }\end{array}$ & $11(100 \%)$ \\
\hline & $\begin{array}{l}\text { Location of tumour } \\
\text { - Body } \\
\text { - Tip } \\
\text { - Body/Base }\end{array}$ & $\begin{array}{ll}3 & (27.3 \%) \\
5 & (45.5 \%) \\
3 & (27.3 \%)\end{array}$ \\
\hline & $\begin{array}{l}\text { Background acute inflammation } \\
\text { - Yes } \\
\text { - No }\end{array}$ & $\begin{array}{l}9(81.81 \%) \\
2(18.18 \%)\end{array}$ \\
\hline & $\begin{array}{l}\text { Histological Staging } \\
\text { - pT1 } \\
\text { - pT2 } \\
\text { - pT3 } \\
\text { - pT4 }\end{array}$ & $\begin{array}{l}6(54.5 \%) \\
3(27.3 \%) \\
1(9.1 \%) \\
1(9.1 \%)\end{array}$ \\
\hline & $\begin{array}{l}\text { Resection margins } \\
\text { - Clear } \\
\text { - Involved } \\
\text { - Mesoappendix extension }\end{array}$ & $\begin{array}{c}9(81.8 \%) \\
1(9.1 \%) \\
1(9.1 \%)\end{array}$ \\
\hline & $\begin{array}{l}\text { Further Treatment } \\
\text { - Right Hemicolectomy } \\
\text { - None }\end{array}$ & $\begin{array}{l}2(18.2 \%) \\
9(81.8 \%)\end{array}$ \\
\hline & $\begin{array}{l}\text { Follow up } \\
\text { - CT Scan } \\
\text { - None }\end{array}$ & $\begin{array}{l}3(27.27 \%) \\
8(72.72 \%)\end{array}$ \\
\hline
\end{tabular}

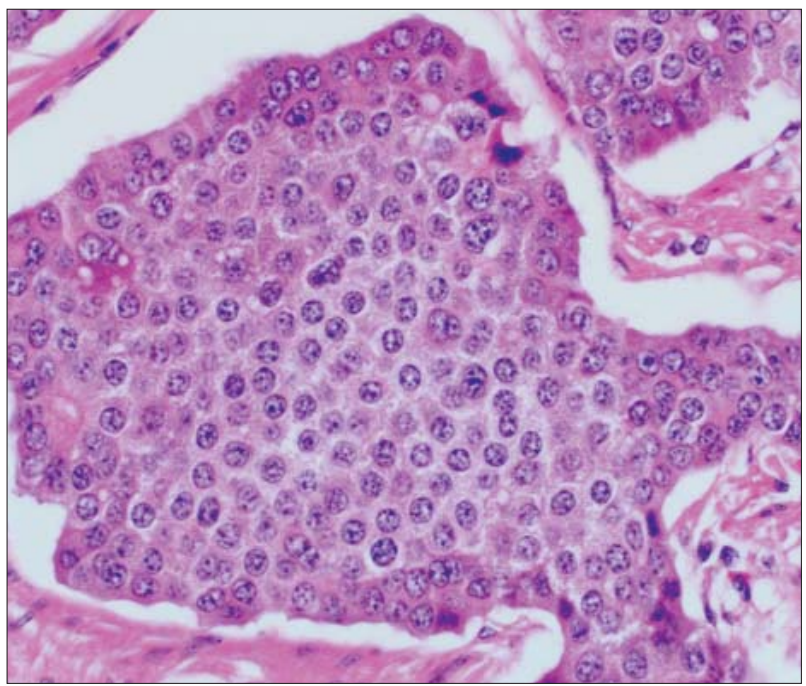

Figure 2. Well differentiated neuroendocrine tumour

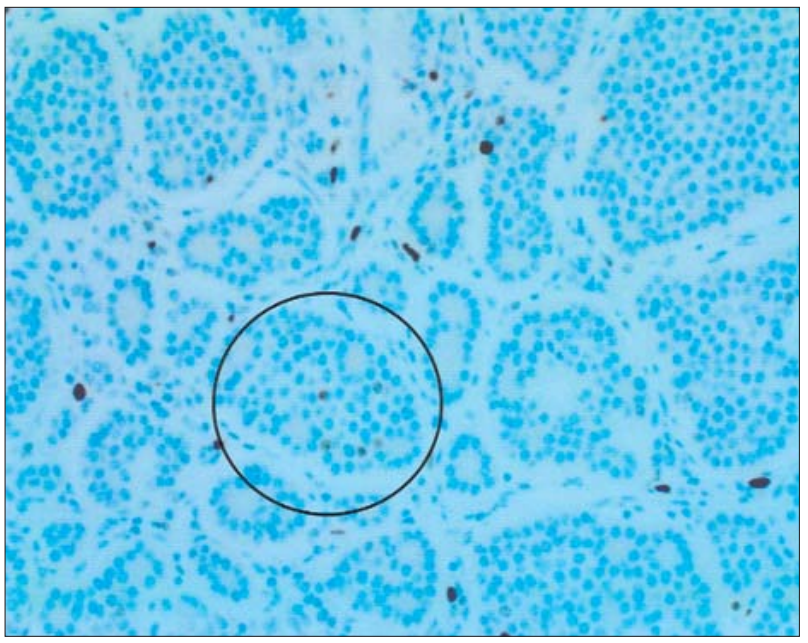

Figure 3. Ki67 (Low Proliferation Index 2\%)

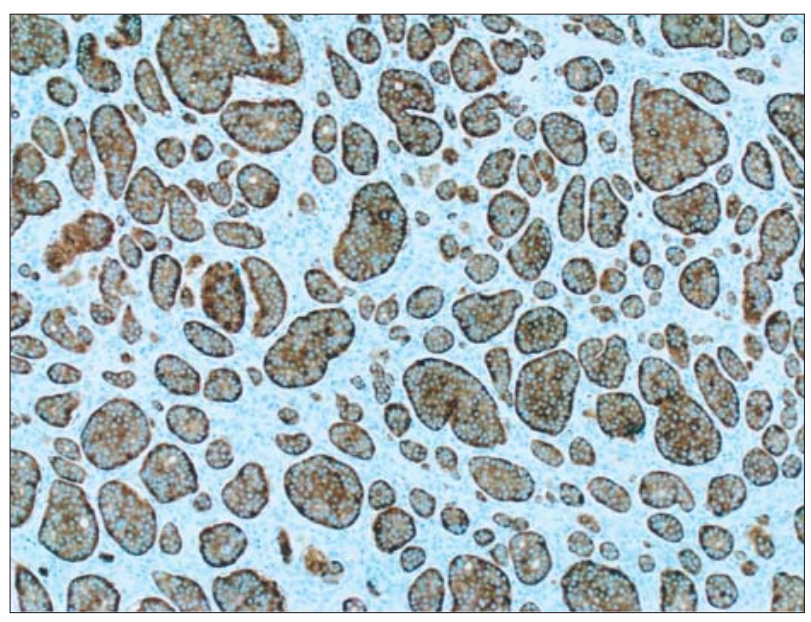

Figure 4. Synaptophysin positive stain (Immunohistochemistry) 
Local multidisciplinary team guidelines were followed. In our series, 3 patients (27.27\%) had follow up scan 2 years after surgery and showed no tumour recur-rence.

\section{Discussion}

Appendiceal neuroendocrine tumour are usually diagnosed incidentally on histological assessment of appendicectomy specimen $(7,10)$. All our patients presented with suspected acute appendicitis and were found to have incidental neuroendocrine tumour. Incidence of incidental ANET was $0.70 \%$ in our series. This corresponds to other studies, where incidence was $0.08 \%$ to $1.6 \%(11-15)$.

Our study confirms that ANEN is more common in 2nd and 3rd decade of life, with female preponderance $(14,16,17)$.

None of patients in our cohort had any suspicion of neoplastic lesion neither during open nor laparoscopic approach for appendicectomy. Hence had standard appendicectomy with or without enbloc resection of mesoappendix. Davenport et al empha-sised on routine enbloc removal of mesoappendix rather than skeletonising appen-dix, while carrying out laparoscopic appendicectomy for acute appendicitis routinely. This will be better for staging of ANEN, should there be any. As unnecessary further surgery, to stage ANEN, can be further avoided (18).

In our cohort, majority of tumours were located in body and base of appendix (54.5\%). This is contrary to other studies, where over 90 $\%$ of ANEN are located at the tip of appendix (14) However, our study corresponds with other studies, where over $80 \%$ of neuroendocrine neoplasms are well differentiated (14).

We followed local guidelines, where treatment of ANEN depends on tumour size, location, mesoappendix invasion, lymph node involvement, proliferation rate \pm angioinvasion $\&$ differentiation of tumour. It is largely based on the European Neuroendocrine Tumour Society guidelines, where appendicectomy will be treatment required for $<1 \mathrm{~cm}$ well differentiated ANEN located at tip and body of appendix. These guidelines recommends onco- $^{-}$ logical right hemicolectomy, for tumours more than $2 \mathrm{~cm}$ and tumours with a size of 1-2 cm but with mesoappendix invasion, involved resection margins, higher proliferation rate (Ki67 labelling index $>2 \%$ ) and/or angioinvasion $(7,19)$. So in our series, 9 patients had favourable biology, as were grade 1 and well differentiated, and size, hence had index appendicectomy. As 2 patients were locally advance, so these patients had oncological right hemicolectomy at later date.

We followed our local guidelines for post operative follow up too. Evidence shows that a long term follow up of small ANET doesn't make a difference to long term sur-vival (16, 20). Hence, in our cohort, three patients, who had follow up scans showed no evidence of metastasis. Rest of patients had no follow up scans as they were considered as low risk. In our cohort, there was no mortality.

Our study has limitations due to retrospective design and small number of cases. A larger study will help in understanding the clinicopathological features as well as incidence of this rare but serious disease.

In our cohort, as patients had clinically acute appendicitis, an appendicectomy was undertaken. This is contrary to recent growing interest of treating appendicitis with antibiotics only $(2,3)$. Treatment of clinically acute appendicitis completely conservatively in our cohort would have missed a window period where a treatable disease with an excellent prognosis, may have became an untreatable disease with a poor prognosis. So, to overcome the problem of missing any small indolent slow growing neoplastic lesion within appendix, it may be a reasonable approach to carryout an interval appendicectomy at a later date. Not only ANENs have been demonstrated incidentally in appendicectomy specimens for acute appendicitis, it's also been reported as incidental findings discovered on histology of interval appendicectomy specimens too, without any clinical suspicion of any neoplasia $(6,21,22)$. Hence, we strongly support the idea of interval appendicectomy rather than managing it completely conservatively 


\section{Conclusion}

Appendiceal neuroendocrine tumours are almost always diagnosed post operatively on the histology review of the specimens. As majority are well differentiated tumours, hence appendicectomy is considered to be the curative procedure. However, if acute appendicitis is managed with conservative treatment with antibiotics, there is less than $1 \%$ risk of missing the diagnosis of ANEN. Two patients, in our study, had locally advance diseases and these could have definitely poor prognosis without appendectomy.

\section{Disclosure Statement}

The authors declare no conflicts of interests.

\section{Acknowledgement}

Authors acknowledge support from Dr Melanie Levy, histopathologist at Barnsley district general hospital for providing histology images.

\section{References}

1. Addiss DG, Shaffer N, Fowler BS, Tauxe RV. The epidemiology of appendicitis and appendectomy in the United States. Am J Epidemiol. 1990; 132: 910-25.

2. Styrud J, Eriksson S, Nilsson I, Ahlberg G, Haapaniemi S, Neovius $G$, et al. Appendectomy versus antibiotic treatment in acute appendicitis. a prospective multicenter randomized controlled trial. World J Surg. 2006; 30: 1033-7.

3. Hansson J, Körner U, Khorram-Manesh A, Solberg A, Lundholm K. Randomized clinical trial of antibiotic therapy versus appendicectomy as primary treatment of acute appendicitis in unselected patients. $\mathrm{Br}$ J Surg. 2009; 96: 473-81.

4. Salminen $P$, Paajanen $H$, Rautio $T$, Nordström $P$, Aarnio $M$, Rantanen $\mathrm{T}$ et al. Antibiotic Therapy vs Appendectomy for Treatment of Uncomplicated Acute Appendicitis: The APPAC Randomized Clinical Trial. JAMA. 2015; 313: 2340-8.

5. Rollins KE, Varadhan KK, Neal KR, Lobo DN. Antibiotics Versus Appendicectomy for the Treatment of Uncomplicated Acute Appendicitis: An Updated Meta-Analysis of Randomised Controlled Trials. World J Surg. 2016; 40: 2305-18.

6. Al-Kurd A, Mizrahi I, Siam B, Kupietzky A, Hiller N, Beglaibter N, et al. Outcomes of interval appendectomy in comparison with appen- dectomy for acute appendicitis. J Surg Res. 2018; 225: 90-4.

7. Pape UF, Niederle B, Costa F, Gross D, Kelestimur F, Kianmanesh R et al. Vienna Consensus Conference: ENETS Consensus Guidelines for Neuroendocrine Neoplasms of the Appendix (Excluding Goblet Cell Carcinomas). Neuroendocrinology. 2016; 103: 144-52.

8. Moris D, Tsilimigras DI, Vagios S, Ntanasis-Stathopoulos I, Karachaliou GS, Papalampros A et al. Neuroendocrine Neoplasms of the Appendix: A Review of the Literature. Anticancer Res. 2018; 38: $601-11$

9. Boudreaux JP, Klimstra DS, Hassan MM, Woltering EA, Jensen RT, Goldsmith SJ et al. The NANETS consensus guideline for the diagnosis and management of neuroendocrine tumors: well-differentiated neuroendocrine tumors of the Jejunum, Ileum, Appendix, and Cecum. Pancreas. 2010; 39:753-66.

10. Masson P. Carcinoids (argentaffin-cell tumors) and nerve hyperplasia of the appendicular mucosa. Am J Pathol. 1928; 4: 181-212.

11. Saylam B, Küçük OK, Düzgün AP, Ozer MV, Coskun F. Carcinoid tumor of the appendix: report on ten cases. Eur J Trauma Emerg Surg. 2011: 37; 491-3.

12. Zhang X, Ma L, Bao H, Zhang J, Wang Z, Gong P. Clinical, pathological and prognostic characteristics of gastroenteropancreatic neuroendocrine neop-lasms in China: a retrospective study. BMC Endocr Disord. 2014; 14: 54-6.

13. Büyükaşık K, Arı A, Tatar C, Akçe B, Sevinç MM, Sarı S, et al. Clinicopatho-logical features of gastroenteropancreatic neuroendocrine tumors: A retros-pective evaluation of 42 cases. Turk J Surg. 2017;33:279-83.

14. Abdelaal A, El Ansari W, Al-Bozom I, Khawar M, Shahid F, Aleter A, et al. Frequency, characteristics and outcomes of appendicular neuroendocrine tumors: A cross-sectional study from an academic tertiary care hospital. Ann Med Surg(Lond). 2017; 21: 20-4.

15. Barretoa SG, Tiong L, Travers E, Williams RS. Incidental appendiceal carcinoids: is surgery affecting their incidence? World $\mathrm{J}$ Oncol. 2012; 3: 227-30.

16. Tchana-Sato V, Detry O, Polus M, Thiry A, Detroz B, Maweja S, et al. Carcinoid tumor of the appendix: a consecutive series from 1237 appendectomies. World J. Gastroenterol. 2006;12:6699-701.

17. Dincel 0 , Göksu M, Türk BA, Pehlivanoğlu $B$, İșler $S$. Unexpected findings in the routine histopathological examinations of appendectomy specimens A retrospective analysis of 1,970 patients. Ann Ital Chir. 2017; 88:519-25.

18. Davenport E, Courtney ED, Benson-Cooper S, Bissett IP. Appendiceal neuroendocrine neoplasms in the era of laparoscopic appendicectomy. ANZ J Surg 2014; 84: 337-40.

19. Pawa N, Clift AK, Osmani H, Drymousis P, Cichocki A, Flora R, et al. Surgical management of Patients with Neuroendocrine Neoplasms of the Appendix: Appendectomy or More. Neuroendocrinology. 2018; 106:242-51.

20. Murray SE, Lloyd RV, Sippel RS, Chen H, Oltmann SC. Postoperative surveillance of small appendiceal carcinoid tumors. Am J. Surg. 2014; 207: 342-5.

21. Henderson L, Fehily C, Folaranmi S, Kelsey A, McPartland J, Jawaid WB et al. Management and outcome of neuroendocrine tumours of the appendix-a two centre UK experience. J Pediatr Surg. 2014; 49: 1513-7.

22. Watanabe HA, Fujimoto T, Kayo Y, Sasaki M, Ikusue T. Acute appendicitis with a neuroendocrine tumor G1 (carcinoid): pitfalls of conservative treatment. Clin J Gastroenterol. 2016; 9; 203-7. 